\title{
Medical History, Lifestyle, Family History, and Occupational Risk Factors for Lymphoplasmacytic Lymphoma/Waldenström's Macroglobulinemia: The InterLymph Non-Hodgkin Lymphoma Subtypes Project
}

Claire M. Vajdic, Ola Landgren, Mary L. McMaster, Susan L. Slager, Angela Brooks-Wilson, Alex Smith, Anthony Staines, Ahmet Dogan, Stephen M. Ansell, Joshua N. Sampson, Lindsay M. Morton, Martha S. Linet

Correspondence to: Claire M. Vajdic, PhD BOptom, Adult Cancer Program, Lowy Cancer Research Centre, Level 4 Faculty of Medicine, University of New South Wales, New South Wales 2052, Australia (e-mail: claire.vajdic@unsw.edu.au).

Background Lymphoplasmacytic lymphoma/Waldenström's macroglobulinemia (LPL/WM), a rare non-Hodgkin lymphoma subtype, shows strong familial aggregation and a positive association with chronic immune stimulation, but evidence regarding other risk factors is very limited.

Methods

The International Lymphoma Epidemiology Consortium (InterLymph) pooled data from 11 predominantly population-based case-control studies from North America, Europe, and Australia to examine medical history, lifestyle, family history, and occupational risk factors for LPL/WM. Age-, sex-, race/ethnicity-, and study-adjusted odds ratios (ORs) and 95\% confidence intervals (Cls) were estimated using logistic regression for a total of 374 LPL/WM cases and 23096 controls.

Results In multivariate analysis including all putative risk factors, LPL/WM risk was associated with history of Sjögren's syndrome $(\mathrm{OR}=14.0,95 \% \mathrm{Cl}=3.60$ to 54.6$)$, systemic lupus erythematosus $(\mathrm{OR}=8.23,95 \% \mathrm{Cl}=2.69$ to 25.2 ), hay fever ( $\mathrm{OR}=0.73,95 \% \mathrm{Cl}=0.54$ to 0.99 ), positive hepatitis $\mathrm{C}$ serology $(\mathrm{OR}=2.51,95 \% \mathrm{Cl}=1.03$ to 6.17 ), hematologic malignancy in a first-degree relative $(\mathrm{OR}=1.64,95 \% \mathrm{Cl}=1.02$ to 2.64$)$, adult weight $(\mathrm{OR}=0.61,95 \%$ $\mathrm{Cl}=0.44$ to 0.85 for highest vs. lowest quartile), duration of cigarette smoking $(\mathrm{OR}=1.46,95 \% \mathrm{Cl}=1.04$ to 2.05 for $\geq 40$ years vs. nonsmokers), and occupation as a medical doctor (OR $=5.54,95 \% \mathrm{Cl}=2.19$ to 14.0 ). There was no association with other medical conditions, lifestyle factors, or occupations.

Conclusions This pooled analysis confirmed associations with immune conditions and family history of hematologic malignancy, and identified new associations with hay fever, weight, smoking, and occupation, and no association with other lifestyle factors. These findings offer clues to LPL/WM biology and prevention.

J Natl Cancer Inst Monogr 2014;48:87-97

Lymphoplasmacytic lymphoma (LPL) is a non-Hodgkin lymphoma (NHL) subtype characterized by the proliferation of small B lymphocytes, plasmacytoid lymphocytes, and plasma cells. Most patients with LPL have IgM paraproteins and a minority have both IgM and IgG or other paraproteins, although this is not diagnostic (1). Waldenström's macroglobulinemia (WM) is a clinicopathological subset of LPL defined as LPL with bone marrow involvement and monoclonal IgM gammopathy (2). LPL/WM is rare, with incidence estimates ranging from 0.031 to $0.043 / 100000$ personyears in Japan and Taiwan (3) to $0.63 / 100000$ person-years in the United States (4).

Established risk factors for LPL/WM are older age, male gender, white race/ethnicity (4), family history of LPL/WM or another B-cell malignancy (5-7), and history of the precursor condition monoclonal gammopathy of undetermined significance of $\operatorname{IgM}$ class $(8,9)$. Other putative risk factors are a history of infectious disease (10-14), autoimmune disease $(11,13-15)$, allergies $(13,14)$, and certain genetic characteristics (16-19). In one study, increased risk of familial LPL/WM ( $=103$ ) was associated with farming and exposure to pesticides, wood dust, and organic solvents (14), whereas another identified no lifestyle or occupational risk factors based on 65 WM cases (20). Together these findings support a role for germline susceptibility genes, antigenic drive, chronic immune stimulation, and possibly occupational factors in LPL/WM carcinogenesis. The largest prior studies have used health record linkage $(7,13)$; thus, there has been no comprehensive evaluation of risk factors for LPL/WM, particularly lifestyle and occupational exposures, and assessment in a multivariate setting.

We investigated LPL/WM associations with medical and family history, lifestyle, and occupational risk factors in a pooled analysis of 374 cases and 23096 controls from 11 case-control studies from Europe, North America, and Australia as part of the International Lymphoma Epidemiology Consortium (InterLymph) NHL Subtypes Project. 


\section{Methods}

\section{Study Design and Population}

Detailed methodology is provided elsewhere in this issue. Studies eligible for inclusion in this pooled analysis of 11 studies met the following criteria: 1) case-control design, with incident, histologically confirmed cases of LPL/WM, and 2) availability of individuallevel data for at least several risk factors of interest by December 31,2011 . Seven studies were population based (21-27), one was a combination of population based and hospital based (28), and three were hospital based (29-31). Most studies excluded individuals with a history of solid organ transplantation or HIV/AIDS.

Contributing studies were approved by local ethics review committees, and all participants provided informed consent before interview.

\section{NHL Subtype Ascertainment and Harmonization}

All LPL/WM cases met the criteria for LPL/WM described by the World Health Organization classification $(1,32)$ and satisfied the classification suggested subsequently by the InterLymph Pathology Working Group (33,34). Most studies confirmed diagnoses by centralized pathology review by at least one expert hematopathologist.

\section{Risk Factor Ascertainment and Harmonization}

Each study collected data on putative NHL risk factors in a standardized, structured format using self-administered questionnaires. Risk factor categories included medical, lifestyle, family, and occupations. A requirement for inclusion was that a factor was ascertained in a minimum of two studies that enrolled at least one case of LPL/WM. Centralized harmonization of individual-level, deidentified data from each study was performed. Each variable was harmonized across studies and then data were reviewed for consistency among related exposure variables.

\section{Statistical Analysis}

Risk of LPL/WM associated with each exposure variable was examined using unconditional logistic regression models adjusted for age, race/ethnicity, sex, and study ("basic adjusted model"). Individuals with missing data for the exposure variable were excluded. Statistical significance was evaluated by a likelihood ratio test, comparing models with and without the exposure variable, with $P$ values less than .05 used to identify putatively influential factors to be considered for the multivariate model. When two highly correlated factors or exposures were significant, only one exposure was taken forward. In such instances, the most clinically meaningful or specific exposure was selected, for example, a specific autoimmune disease rather than the composite autoimmune disease variable. Further, if the $P$ value for only one exposure from several related exposures was less than.05, it was not automatically examined in the multivariate model. In these cases, the balance of evidence was taken into account, including whether there was evidence of a dose-response.

To evaluate potential effect of heterogeneity among the 11 studies, we performed a separate logistic regression within each study and then quantified the variability of the coefficients by the $H$ statistic, adapting the definition by Higgins and Thompson (35) to categorical variables.
We then examined the relationship between case/control status and each putative risk factor considering possible effect modification and accounting for other potential confounders. To consider possible effect modification, we repeated the basic adjusted models and stratified individuals by age $(<30,30-39,40-49,50-59,60-69$, $70-79$, and $\geq 80$ years), sex, race/ethnicity, region (North America, Northern Europe, Southern Europe, and Australia), study, study design, and other putative risk factors identified in the analysis. To account for other potential confounders, we conducted two analyses. First, we evaluated the risk estimate for each putative risk factor in a series of models that adjusted for one other putative risk factor as well as age, sex, race/ethnicity, and study. Second, we assessed all putative risk factors in a multivariate logistic regression model, this time including a separate missing category for each variable to ensure that the whole study population was included in the analysis. Lastly, we conducted a forward stepwise logistic regression adding a single putative risk factor at a time, adjusting for age, sex, race/ethnicity, and study ("final model").

As controls for most original studies were chosen to frequency match the age and sex of all eligible lymphoma cases, rather than just LPL/WM, we conducted sensitivity analyses using a subset of controls that were frequency matched by age and sex to cases of

Table 1. Characteristics of the pooled lymphoplasmacytic lymphoma/Waldenström's macroglobulinemia case and control participants

\begin{tabular}{|c|c|c|}
\hline Characteristic & $\begin{array}{c}\text { Cases, No. }(\%) \\
\quad(n=374)\end{array}$ & $\begin{array}{l}\text { Controls, No. }(\%) \\
(n=23096)\end{array}$ \\
\hline \multicolumn{3}{|l|}{ Age, y } \\
\hline$<30$ & $2(0.5)$ & $1306(5.9)$ \\
\hline $30-39$ & $7(1.9)$ & $2180(9.4)$ \\
\hline $40-49$ & $33(8.8)$ & $3159(13.7)$ \\
\hline $50-59$ & $90(24.1)$ & $4992(21.6)$ \\
\hline $60-69$ & $128(34.2)$ & $6380(27.6)$ \\
\hline $70-79$ & $96(25.7)$ & $4136(17.9)$ \\
\hline$\geq 80$ & $17(4.5)$ & $873(3.8)$ \\
\hline Unknown & $1(0.3)$ & $16(0.1)$ \\
\hline \multicolumn{3}{|l|}{ Sex } \\
\hline Male & $227(60.7)$ & $13495(58.4)$ \\
\hline Female & 147 (39.3) & $9601(41.6)$ \\
\hline \multicolumn{3}{|l|}{ Race/ethnicity } \\
\hline White non-Hispanic & $352(94.1)$ & 21576 (93.4) \\
\hline Black & $4(1.1)$ & $351(1.5)$ \\
\hline Asian & $3(0.8)$ & $321(1.4)$ \\
\hline Hispanic & $1(0.3)$ & $360(1.6)$ \\
\hline Other/unknown & $14(3.7)$ & $488(2.1)$ \\
\hline \multicolumn{3}{|l|}{ Socioeconomic status* } \\
\hline Low & $142(38.0)$ & $9335(40.4)$ \\
\hline Medium & $108(28.9)$ & $6709(29.0)$ \\
\hline High & 118 (31.6) & $6642(28.8)$ \\
\hline Other/unknown & $6(1.6)$ & 410 (1.8) \\
\hline \multicolumn{3}{|l|}{ Region } \\
\hline North America & $156(41.7)$ & 11462 (49.6) \\
\hline Northern Europe & $156(41.7)$ & $6542(28.3)$ \\
\hline Southern Europe & $35(9.4)$ & $4398(19.0)$ \\
\hline Australia & $27(7.2)$ & $694(3.0)$ \\
\hline \multicolumn{3}{|l|}{ Study design } \\
\hline Population based & $291(77.8)$ & $17846(77.3)$ \\
\hline Hospital based & $83(22.2)$ & $5250(22.7)$ \\
\hline
\end{tabular}

* Socioeconomic status was measured by years of education for studies in North America or by dividing measures of education or socioeconomic status into tertiles for studies in Europe or Australia. 
Table 2. Basic adjusted association between personal history of autoimmune or allergic disease and lymphoplasmacytic lymphoma/ Waldenström's macroglobulinemia (LPL/WM) risk*

\begin{tabular}{|c|c|c|c|c|}
\hline Diseaset & Cases, No.‡ & Controls, No.‡ & OR $(95 \% \mathrm{Cl}) \S$ & $P$ \\
\hline \multicolumn{5}{|l|}{ Autoimmune diseases } \\
\hline \multicolumn{5}{|l|}{ Sjögren syndrome } \\
\hline No & 174 & 6079 & Referent & .003 \\
\hline Yes & 3 & 9 & 13.2 (3.42 to 50.9$)$ & \\
\hline \multicolumn{5}{|l|}{ Systemic lupus erythematosus } \\
\hline No & 270 & 10470 & Referent & .002 \\
\hline Yes & 4 & 24 & $8.73(2.91$ to 26.2$)$ & \\
\hline \multicolumn{5}{|l|}{ Myasthenia gravis } \\
\hline No & 228 & 7506 & Referent & .171 \\
\hline Yes & 1 & 4 & $6.60(0.70$ to 62.3$)$ & \\
\hline \multicolumn{5}{|l|}{ Sarcoidosis } \\
\hline No & 318 & 9379 & Referent & .362 \\
\hline Yes & 2 & 27 & $2.11(0.49$ to 9.01$)$ & \\
\hline \multicolumn{5}{|l|}{ Rheumatoid arthritis\| } \\
\hline No & 208 & 6368 & Referent & .474 \\
\hline Yes & 4 & 82 & $1.48(0.53$ to 4.13$)$ & \\
\hline \multicolumn{5}{|l|}{ Celiac disease } \\
\hline No & 268 & 7593 & Referent & .790 \\
\hline Yes & 1 & 25 & $1.33(0.18$ to 10.1$)$ & \\
\hline \multicolumn{5}{|l|}{ Crohn's disease } \\
\hline No & 315 & 9787 & Referent & .994 \\
\hline Yes & 1 & 29 & $0.99(0.13$ to 7.48$)$ & \\
\hline \multicolumn{5}{|l|}{ Type 1 diabetes } \\
\hline No & 207 & 7402 & Referent & .967 \\
\hline Yes & 1 & 43 & $0.96(0.13$ to 7.09$)$ & \\
\hline \multicolumn{5}{|l|}{ Psoriasis } \\
\hline No & 199 & 7333 & Referent & .819 \\
\hline Yes & 7 & 228 & $0.92(0.42$ to 1.98$)$ & \\
\hline \multicolumn{5}{|l|}{ Inflammatory bowel disorder } \\
\hline No & 343 & 10932 & Referent & .825 \\
\hline Yes & 4 & 111 & $0.89(0.32$ to 2.47$)$ & \\
\hline \multicolumn{5}{|l|}{ Ulcerative colitis } \\
\hline No & 279 & 7777 & Referent & .849 \\
\hline Yes & 3 & 81 & $0.89(0.28$ to 2.89$)$ & \\
\hline \multicolumn{5}{|l|}{ Polymyositis or dermatomyositis } \\
\hline No & 61 & 3580 & Referent & .419 \\
\hline Yes & 0 & 18 & - & \\
\hline \multicolumn{5}{|l|}{ Multiple sclerosis } \\
\hline No & 314 & 9365 & Referent & .332 \\
\hline Yes & 0 & 13 & - & \\
\hline \multicolumn{5}{|l|}{ Pernicious anemia } \\
\hline No & 71 & 3146 & Referent & .401 \\
\hline Yes & 0 & 8 & - & \\
\hline \multicolumn{5}{|l|}{ Hemolytic anemia } \\
\hline No & 94 & 3793 & Referent & .562 \\
\hline Yes & 0 & 7 & - & \\
\hline Systemic sclerosis or sclerode & & & & \\
\hline No & 142 & 3848 & Referent & .576 \\
\hline Yes & 0 & 4 & - & \\
\hline Any autoimmune disease & & & & \\
\hline None & 349 & 11911 & Referent & .054 \\
\hline B-cell activation & 10 & 121 & $2.78(1.43$ to 5.43$)$ & \\
\hline T-cell activation & 15 & 444 & $1.02(0.60$ to 1.74$)$ & \\
\hline Both $\mathrm{B}$ - and T-cell activation & 0 & 12 & - & \\
\hline Atopic disorders & & & & \\
\hline Hay fever & & & & \\
\hline No & 218 & 7235 & Referent & .022 \\
\hline Yes & 64 & 2511 & $0.70(0.51$ to 0.96$)$ & \\
\hline Asthma & & & & \\
\hline No & 295 & 9923 & Referent & .932 \\
\hline Yes & 33 & 1075 & $0.98(0.68$ to 1.42$)$ & \\
\hline
\end{tabular}

(Table Continues) 
Table 2. Continued

\begin{tabular}{|c|c|c|c|c|}
\hline Diseaset & Cases, No.‡ & Controls, No.‡ & OR $(95 \% \mathrm{Cl}) \S$ & $P$ \\
\hline \multicolumn{5}{|l|}{ Eczema } \\
\hline No & 309 & 9941 & Referent & .891 \\
\hline Yes & 36 & 1291 & $0.98(0.68$ to 1.39$)$ & \\
\hline \multicolumn{5}{|c|}{ Any specific allergy\# } \\
\hline No & 226 & 7233 & Referent & .409 \\
\hline Yes & 92 & 3168 & 0.90 (0.69 to 1.16$)$ & \\
\hline \multicolumn{5}{|c|}{ Food allergy } \\
\hline No & 274 & 8939 & Referent & .157 \\
\hline Yes & 20 & 908 & $0.72(0.45$ to 1.16$)$ & \\
\hline \multicolumn{5}{|c|}{ Any atopic disorder** } \\
\hline No & 225 & 7392 & Referent & .229 \\
\hline Yes & 140 & 4868 & 0.87 (0.70 to 1.09$)$ & \\
\hline
\end{tabular}

* $\mathrm{Cl}=$ confidence interval; OR = odds ratio.

† Self-reported condition diagnosed at least 2 years before LPLMM diagnosis/interview.

¥ The counts do not add up to the total number of cases/controls due to data missing by design or report.

$\S$ Adjusted for age, sex, race/ethnicity, and study.

\|I Only those who also reported receiving corticosteroid or immunosuppressive treatment for rheumatoid arthritis.

If Includes self-reported history of specific autoimmune diseases occurring $\geq 2$ years before diagnosis/interview (except the New South Wales study, which did not ascertain date of onset). Autoimmune diseases were classified according to whether they are primarily mediated by B-cell or T-cell responses. B-cell-activating diseases included Hashimoto thyroiditis, hemolytic anemia, myasthenia gravis, pernicious anemia, rheumatoid arthritis, Sjögren's syndrome, and systemic lupus erythematosus. T-cell-activating diseases included celiac disease, immune thrombocytopenic purpura, inflammatory bowel disorder (Crohn's disease, ulcerative colitis), multiple sclerosis, polymyositis or dermatomyositis, psoriasis, sarcoidosis, systemic sclerosis or scleroderma, and type 1 diabetes.

\# Any specific allergy included plant, food, animal, dust, insect, or mold and excluded drug allergies, asthma, eczema, and hay fever.

**Atopic disorders include asthma, eczema, hay fever, or other allergies, excluding drug allergies.

LPL/WM. The results from these sensitivity analyses were very similar to the results obtained using the full set of controls. We thus retained the full set of controls for our main analyses to maximize statistical power.

Analyses were conducted using SAS software, version 9.2 (SAS Institute Inc, Cary, NC).

\section{Results}

A total of $374 \mathrm{LPL} / \mathrm{WM}$ cases $(371 \mathrm{LPL}$ and $3 \mathrm{WM}$; diagnosed 1995-2008) and 23096 controls were included in this study. Most cases were identified in case-control studies in North America or Northern Europe (Table 1). Sixty-one percent of cases were men and the median age at diagnosis was 64 years (range 27-89). Compared with controls, cases were older and more likely to be men, but there was no difference by race/ethnicity or socioeconomic status (Table 1).

There was no statistically significant between-study heterogeneity for any of the risk factors examined (data not shown), and there was no evidence of effect modification by study, study design factors, or the other putative risk factors examined (data not shown).

\section{Basic Adjusted Model}

Medical History. Twenty-five LPL/WM cases (7.2\%) and 577 controls (4.6\%) had a history of autoimmune disease (Table 2); two cases and 26 controls reported more than one. These two cases reported rheumatoid arthritis and Sjögren's syndrome, as did two of the controls. Individually, Sjögren's syndrome and systemic lupus erythematosus were very strongly associated with LPL/WM risk, but the case numbers were too small to examine the relationship with disease latency $(n=3$ and $n=4$, respectively; Table 2). There was no association between LPL/WM risk and history of other selected autoimmune conditions (Table 2).
Risk was strongly increased in association with autoimmune disease characterized by $\mathrm{B}$-cell activation but not $\mathrm{T}$-cell activation (Table 2). LPL/WM risk was inversely associated with a history of hay fever (odds ratio $[\mathrm{OR}]=0.70,95 \%$ confidence interval

Table 3. Basic adjusted association between first-degree family history of hematological malignancy and lymphoplasmacytic lymphoma/Waldenström's macroglobulinemia risk*

\begin{tabular}{|c|c|c|c|c|}
\hline $\begin{array}{l}\text { Family member malignancy } \\
\text { type and relationship to } \\
\text { case/controlt }\end{array}$ & $\begin{array}{c}\text { Cases, } \\
\text { No.f }\end{array}$ & $\begin{array}{c}\text { Controls, } \\
\text { No.f }\end{array}$ & $\begin{array}{l}\text { OR }(95 \% \\
\text { Cl)§ }\end{array}$ & $P$ \\
\hline \multicolumn{5}{|l|}{ Any hematological malignancy } \\
\hline No & 177 & 7303 & Referent & .050 \\
\hline Yes & 21 & 452 & $\begin{array}{l}1.65 \text { (1.03 to } \\
2.65)\end{array}$ & \\
\hline \multicolumn{5}{|l|}{ Hodgkin lymphoma } \\
\hline No & 166 & 6496 & Referent & .369 \\
\hline Yes & 2 & 34 & $\begin{array}{r}2.10(0.48 \\
\text { to } 9.10)\end{array}$ & \\
\hline \multicolumn{5}{|l|}{ Non-Hodgkin lymphoma } \\
\hline No & 172 & 6837 & Referent & .683 \\
\hline Yes & 6 & 197 & $\begin{array}{r}1.20(0.52 \\
\text { to } 2.76)\end{array}$ & \\
\hline \multicolumn{5}{|l|}{ Leukemia\| } \\
\hline No & 165 & 6819 & Referent & .018 \\
\hline Yes & 13 & 215 & $\begin{array}{r}2.19(1.21 \\
\text { to } 3.96)\end{array}$ & \\
\hline \multicolumn{5}{|l|}{ Multiple myeloma } \\
\hline No & 168 & 6496 & Referent & .143 \\
\hline Yes & 0 & 34 & - & \\
\hline
\end{tabular}

* $\mathrm{Cl}=$ confidence interval; $\mathrm{OR}=$ odds ratio.

† Self-reported family history; some participants had more than one affected relative.

$\ddagger$ The counts do not add up to the total number of cases/controls due to data missing by design or report.

$\S$ Adjusted for age, sex, race/ethnicity, and study.

I| Leukemia includes chronic lymphocytic leukemia/small lymphocytic lymphoma. 
Table 4. Basic adjusted association between lifestyle factors and lymphoplasmacytic lymphoma/Waldenström's macroglobulinemia risk*

\begin{tabular}{|c|c|c|c|c|}
\hline Lifestyle factor & Cases, No.t & Controls, No.t & OR $(95 \% \mathrm{Cl}) \neq$ & $P$ \\
\hline Adult height & & & & .731 \\
\hline Quartile 1 (low) & 82 & 2787 & Referent & \\
\hline Quartile 2 & 85 & 2816 & $0.97(0.70$ to 1.33$)$ & \\
\hline Quartile 3 & 75 & 2747 & 0.82 (0.59 to 1.14$)$ & \\
\hline Quartile 4 (high) & 82 & 2873 & $0.93(0.67$ to 1.29$)$ & \\
\hline \multicolumn{5}{|l|}{ Usual adult weight§ } \\
\hline Quartile 1 (low) & 88 & 2432 & Referent & .015 \\
\hline Quartile 2 & 66 & 2377 & $0.68(0.49$ to 0.95$)$ & \\
\hline Quartile 3 & 91 & 3115 & $0.70(0.52$ to 0.95$)$ & \\
\hline Quartile 4 (high) & 79 & 3299 & 0.60 (0.44 to 0.83$)$ & \\
\hline \multicolumn{5}{|l|}{ Usual adult BMII (kg/m²) } \\
\hline $15-<18.5$ & 4 & 178 & 0.74 (0.26 to 2.10$)$ & \\
\hline $18.5-<22.5$ & 67 & 2058 & Referent & .034 \\
\hline $22.5-<25$ & 90 & 2659 & $0.86(0.62$ to 1.20$)$ & \\
\hline $25-<30$ & 124 & 4335 & 0.69 (0.50 to 0.94$)$ & \\
\hline $30-<35$ & 31 & 1454 & 0.56 (0.36 to 0.87$)$ & \\
\hline $35-50$ & 8 & 539 & $0.43(0.20$ to 0.91$)$ & \\
\hline \multicolumn{5}{|l|}{ BMl as a young adult $\left(\mathrm{kg} / \mathrm{m}^{2}\right)$} \\
\hline $15-<18.5$ & 9 & 226 & 1.71 (0.79 to 3.70$)$ & \\
\hline $18.5-<22.5$ & 36 & 1432 & Referent & .624 \\
\hline $22.5-<25$ & 21 & 667 & $1.32(0.74$ to 2.35$)$ & \\
\hline $25-<30$ & 8 & 362 & $0.93(0.41$ to 2.08$)$ & \\
\hline $30-50$ & 1 & 82 & $0.86(0.11$ to 6.61$)$ & \\
\hline \multicolumn{5}{|l|}{ Physical activity } \\
\hline None & 18 & 686 & Referent & .617 \\
\hline Mild & 15 & 426 & 1.08 (0.49 to 2.37$)$ & \\
\hline Moderate & 30 & 883 & $0.95(0.47$ to 1.90$)$ & \\
\hline Vigorous & 55 & 3027 & $0.68(0.38$ to 1.22$)$ & \\
\hline \multicolumn{5}{|l|}{ History of cigarette smoking\| } \\
\hline No & 118 & 4935 & Referent & .076 \\
\hline Yes & 188 & 5782 & 1.25 (0.98 to 1.59$)$ & \\
\hline \multicolumn{5}{|l|}{ Cigarette smoking status } \\
\hline Nonsmoker & 118 & 4935 & Referent & .354 \\
\hline Former smoker & 126 & 3616 & 1.22 (0.94 to 1.59$)$ & \\
\hline Current smoker & 59 & 2090 & $1.31(0.95$ to 1.82$)$ & \\
\hline Smoker, status unknown & 3 & 76 & $1.18(0.28$ to 4.93$)$ & \\
\hline \multicolumn{5}{|l|}{ Age started smoking cigarettes } \\
\hline Nonsmoker & 118 & 4935 & Referent & .386 \\
\hline$<14$ years & 15 & 514 & $1.16(0.67$ to 2.03$)$ & \\
\hline $14-<18$ years & 76 & 2401 & 1.21 (0.89 to 1.63$)$ & \\
\hline $18-<20$ years & 36 & 1224 & $1.11(0.76$ to 1.63$)$ & \\
\hline$\geq 20$ years & 60 & 1583 & 1.45 (1.05 to 2.00$)$ & \\
\hline Smoker, age started unknown & 1 & 60 & $0.79(0.11$ to 5.82$)$ & \\
\hline \multicolumn{5}{|l|}{ Years since quitting smoking } \\
\hline Nonsmoker & 118 & 4935 & Referent & .304 \\
\hline$>25$ years ago & 38 & 1160 & $1.01(0.69$ to 1.48$)$ & \\
\hline $16-25$ years ago & 38 & 947 & 1.35 (0.92 to 1.97$)$ & \\
\hline $5-15$ years ago & 30 & 963 & $1.22(0.81$ to 1.84$)$ & \\
\hline$<5$ years ago & 16 & 496 & $1.38(0.81$ to 2.37$)$ & \\
\hline Former smoker, unknown when quit & 4 & 50 & 3.01 (1.05 to 8.67$)$ & \\
\hline Current smoker & 59 & 2090 & 1.32 (0.95 to 1.83$)$ & \\
\hline \multicolumn{5}{|l|}{ Smoking frequency } \\
\hline Nonsmoker & 118 & 4935 & Referent & .086 \\
\hline$\leq 10$ cigarettes/day & 76 & 2125 & $1.37(1.02$ to 1.85$)$ & \\
\hline $11-20$ cigarettes/day & 71 & 2387 & $1.12(0.83$ to 1.53$)$ & \\
\hline $21-30$ cigarettes/day & 23 & 548 & $1.72(1.07$ to 2.77$)$ & \\
\hline$>30$ cigarettes/day & 11 & 529 & $0.76(0.40$ to 1.44$)$ & \\
\hline Smoker, frequency unknown & 7 & 193 & 1.45 (0.65 to 3.22$)$ & \\
\hline Continuous (per-year) & & & $1.00(1.00$ to 1.00$)$ & .390 \\
\hline \multicolumn{5}{|l|}{ Duration of cigarette smoking } \\
\hline Nonsmoker & 118 & 4935 & Referent & .324 \\
\hline $1-20$ years & 44 & 2007 & $1.01(0.71$ to 1.44$)$ & \\
\hline
\end{tabular}

(Table Continues) 
Table 4. Continued

\begin{tabular}{|c|c|c|c|c|}
\hline Lifestyle factor & Cases, No.† & Controls, No.t & OR $(95 \% \mathrm{Cl}) \mp$ & $P$ \\
\hline $\begin{array}{l}21-30 \text { years } \\
30-39 \text { years }\end{array}$ & $\begin{array}{l}39 \\
46\end{array}$ & $\begin{array}{l}1258 \\
1235\end{array}$ & $\begin{array}{l}1.23(0.84 \text { to } 1.79) \\
1.32(0.93 \text { to } 1.89)\end{array}$ & \\
\hline$\geq 40$ years & 57 & 1194 & 1.49 (1.06 to 2.09$)$ & \\
\hline Smoker, duration unknown & 2 & 88 & $1.14(0.27$ to 4.75$)$ & \\
\hline Continuous (per-year) & & & $1.01(1.00$ to 1.02$)$ & .022 \\
\hline \multicolumn{5}{|l|}{ Lifetime cigarette exposure } \\
\hline Nonsmoker & 118 & 4935 & Referent & .612 \\
\hline $1-10$ pack-years & 52 & 1827 & $1.27(0.91$ to 1.78$)$ & \\
\hline 11-20 pack-years & 35 & 1206 & $1.13(0.76$ to 1.66$)$ & \\
\hline 21-35 pack-years & 44 & 1274 & 1.25 (0.87 to 1.78$)$ & \\
\hline$\geq 36$ pack-years & 50 & 1247 & $1.33(0.93$ to 1.89$)$ & \\
\hline Smoker, pack-years unknown & 7 & 228 & 1.24 (0.56 to 2.75$)$ & \\
\hline Continuous (per-year) & & & $1.00(1.00$ to 1.01$)$ & .376 \\
\hline \multicolumn{5}{|l|}{ History of alcohol consumption } \\
\hline Nondrinker & 42 & 1960 & Referent & .808 \\
\hline Drinker & 135 & 4621 & $1.04(0.71$ to 1.53$)$ & \\
\hline \multicolumn{5}{|l|}{ Alcohol consumption status } \\
\hline Nondrinker & 42 & 1960 & Referent & .812 \\
\hline Former drinker & 16 & 583 & 1.45 (0.76 to 2.78$)$ & \\
\hline Current drinker & 78 & 3200 & $1.01(0.62$ to 1.65$)$ & \\
\hline Drinker, status unknown & 41 & 838 & 0.96 (0.51 to 1.82$)$ & \\
\hline
\end{tabular}

* $\mathrm{BMI}=$ body mass index; $\mathrm{Cl}=$ confidence interval; $\mathrm{OR}=$ odds ratio.

† The counts do not add up to the total number of cases/controls due to data missing by design or report.

$\ddagger$ Adjusted for age, sex, race/ethnicity, and study.

§ Quartile 1 (<72.6 kg males, <58.1 kg females), quartile 2 (72.6-79.9 kg males, $58.1-64.9 \mathrm{~kg}$ females), quartile 3 (80.0-88.9 kg males, 65.0-74.7 kg females), and quartile 4 ( $\geq 89.0 \mathrm{~kg}$ males, $\geq 74.8 \mathrm{~kg}$ females).

$\|$ Smoked longer than 6 months or more than 100 cigarettes in a lifetime.

ๆ At least one drink per month.

$[\mathrm{CI}]=0.51$ to 0.96 ) but was unrelated to history of asthma, eczema, any specific allergy, or any atopic condition (Table 2).

LPL/WM risk was strongly increased in association with positive serology for hepatitis $\mathrm{C}$ virus $(\mathrm{HCV})$ infection $(\mathrm{OR}=2.70,95 \%$ $\mathrm{CI}=1.11$ to $6.56 ; \mathrm{n}=6$ ). No other infectious diseases were examined. Risk was not associated with the receipt of one or more blood transfusions $(\mathrm{OR}=1.06,95 \% \mathrm{CI}=0.74$ to 1.53$)$, transfusion age, transfusion number, or year of transfusion (data not shown). Neither history of gastric ulcer nor peptic ulcer predicted LPL/WM risk (data not shown).

LPL/WM risk was associated with the number of children $(P=.023)$; relative to women with a single child, risk was decreased for women with no children $(\mathrm{OR}=0.32,95 \% \mathrm{CI}=0.12$ to 0.87$)$ and two children $(\mathrm{OR}=0.34,95 \% \mathrm{CI}=0.15$ to 0.77$)$ but was attenuated and not statistically significant for three or more children $(\mathrm{OR}=0.63,95 \% \mathrm{CI}=0.32$ to 1.22$)$. As LPL/WM risk was not associated with time since the last birth, oral contraceptive use, the age contraceptives were first used, hormone replacement therapy, or the age hormone replacement therapy was first used (data not shown), this variable was not taken forward to multivariable analysis.

Family History. Hematological malignancy in one or more firstdegree relatives was reported by 21 cases (10.6\%) and 452 controls (5.8\%). Risk was moderately increased for having a family member with history of any hematological malignancy $(\mathrm{OR}=1.65,95 \%$ $\mathrm{CI}=1.03$ to 2.65$)$ or with leukemia $(\mathrm{OR}=2.19,95 \% \mathrm{CI}=1.21$ to 3.96). There was no association between LPL/WM risk and family history of Hodgkin lymphoma, NHL, or multiple myeloma (Table 3).
Lifestyle Factors. Usual adult weight was inversely associated with risk of LPL/WM $(P=.015)$; relative to the first quartile, LPL/ WM risk was 0.68 (95\% CI $=0.49$ to 0.95 ) for the second quartile, $0.70(95 \% \mathrm{CI}=0.52$ to 0.95$)$ for the third quartile, and 0.60 (95\% CI $=0.44$ to 0.83 ) for the fourth quartile. The same association was observed for body mass index as an adult $(P=.034)$, but not body mass index as a young adult $(P=.63$; Table 4$)$. Neither usual adult height nor physical activity predicted LPL/WM risk (Table 4).

Ever smoking cigarettes was unrelated to LPL/WM risk $(\mathrm{OR}=1.25,95 \% \mathrm{CI}=0.98$ to 1.59$)$. There was also no association with smoking status, years since quitting, pack-years, or frequency of smoking (Table 4). LPL/WM risk was elevated for those who started smoking when they were at least 20 years of age $(\mathrm{OR}=1.45$, $95 \% \mathrm{CI}=1.05$ to 2.00 , relative to nonsmokers). LPL/WM risk was also positively associated with duration of cigarette smoking, both when examined as a continuous variable $(P=.022)$, and for the highest category of smoking duration $(\mathrm{OR}=1.49,95 \% \mathrm{CI}=1.06$ to 2.09 , for $\geq 40$ years relative to nonsmokers; Table 4 ).

LPL/WM risk was not associated with any measure of alcohol consumption, including ever drinking alcohol $(\mathrm{OR}=1.04$, 95\% $\mathrm{CI}=0.71$ to 1.53$)$, consumption 2 years before diagnosis/interview (Table 4), or age started, duration, servings per week as an adult, lifetime consumption, or beer, liquor, or wine consumption (data not shown).

Sun exposure history was unrelated to LPL/WM risk, either total $(\mathrm{OR}=0.86,95 \% \mathrm{CI}=0.49$ to 1.52 for highest vs. lowest quartile) or recreational $(\mathrm{OR}=0.83,95 \% \mathrm{CI}=0.59$ to 1.18 for highest 
Table 5. Basic adjusted association between farm residence or farm/animal-related occupation and lymphoplasmacytic lymphoma/ Waldenström's macroglobulinemia risk*

\begin{tabular}{|c|c|c|c|c|}
\hline Personal farm-related history & Cases, No.t & Controls, No.t & OR $(95 \% \mathrm{Cl}) \ddagger$ & $P$ \\
\hline \multicolumn{5}{|l|}{ Ever lived or worked on a farm } \\
\hline No & 143 & 5424 & Ref & \multirow[t]{2}{*}{.744} \\
\hline Yes & 65 & 3170 & $0.95(0.67$ to 1.33$)$ & \\
\hline \multicolumn{5}{|l|}{ Ever lived on a farm } \\
\hline No & 66 & 3230 & Ref & \multirow[t]{2}{*}{.262} \\
\hline Yes & 45 & 2617 & 0.79 (0.53 to 1.19$)$ & \\
\hline \multicolumn{5}{|l|}{ Ever worked on a farm } \\
\hline No & 166 & 6727 & Ref & \multirow[t]{2}{*}{.651} \\
\hline Yes & 27 & 1210 & $0.90(0.58$ to 1.40$)$ & \\
\hline \multicolumn{5}{|l|}{ Any farming occupation§ } \\
\hline No & 156 & 6189 & Ref & \multirow[t]{2}{*}{.563} \\
\hline Yes & 27 & 835 & 1.14 (0.73 to 1.78$)$ & \\
\hline \multicolumn{5}{|l|}{ Animal farming } \\
\hline No & 178 & 6847 & Ref & \multirow[t]{2}{*}{.929} \\
\hline Yes & 5 & 177 & $0.96(0.38$ to 2.41$)$ & \\
\hline \multicolumn{5}{|l|}{ Crop farming } \\
\hline No & 174 & 6757 & Ref & \multirow[t]{2}{*}{.736} \\
\hline Yes & 9 & 267 & 1.14 (0.55 to 2.37$)$ & \\
\hline \multicolumn{5}{|l|}{ Field crop and vegetables } \\
\hline No & 131 & 5520 & Ref & \multirow[t]{2}{*}{.588} \\
\hline Yes & 5 & 115 & 1.35 (0.48 to 3.78$)$ & \\
\hline \multicolumn{5}{|l|}{ Mixed animal and crop } \\
\hline No & 163 & 6036 & Ref & \multirow[t]{2}{*}{.697} \\
\hline Yes & 15 & 455 & 1.12 (0.64 to 1.96$)$ & \\
\hline \multicolumn{5}{|l|}{ General farmer } \\
\hline No & 152 & 5491 & Ref & \multirow[t]{2}{*}{.519} \\
\hline Yes & 10 & 272 & 1.26 (0.64 to 2.47$)$ & \\
\hline \multicolumn{5}{|l|}{ Forestry worker } \\
\hline No & 158 & 5740 & Ref & \multirow[t]{2}{*}{$.066 \|$} \\
\hline Yes & 4 & 34 & 3.17 (1.08 to 9.34$)$ & \\
\hline \multicolumn{5}{|l|}{ Meat worker } \\
\hline No & 181 & 6958 & Ref & \multirow[t]{2}{*}{.960} \\
\hline Yes & 2 & 66 & $1.03(0.25$ to 4.35$)$ & \\
\hline
\end{tabular}

${ }^{*} \mathrm{Cl}=$ confidence interval; $\mathrm{OR}=$ odds ratio.

†The counts do not add up to the total number of cases/controls due to data missing by design or report.

¥ Adjusted for age, sex, race/ethnicity, and study.

$\S$ Occupation at any time in life (eight studies) or the longest held occupation (two studies); occupations coded according to the International Standard Classification of Occupations (ISCO), Revised Edition 1968 (53)

$\| P$ value using likelihood ratio test; $P$ value using Wald test .036.

vs. lowest quartile). No measure of hair dye use in women predicted risk of LPL/WM (data not shown).

Occupations. On the basis of four exposed cases (2.5\%), LPL/ WM risk was positively associated with occupation as a forestry worker $(\mathrm{OR}=3.17,95 \% \mathrm{CI}=1.08$ to 9.34$)$. There was no association between risk of LPL/WM and any other farming or animalrelated occupation or farm residence (Table 5). Risk was increased for medical doctors ( $\mathrm{n}=6$ exposed cases, $\mathrm{OR}=5.23,95 \% \mathrm{CI}=2.11$ to 12.9 ), specifically those working in this occupation for more than 10 years $(\mathrm{n}=5$ exposed cases, $\mathrm{OR}=12.7,95 \% \mathrm{CI}=4.41$ to 36.8$)$. There was no association between LPL/WM risk and all medical occupations combined $(\mathrm{OR}=1.42,95 \% \mathrm{CI}=0.84$ to 2.41$)$.

\section{Final Model}

We observed no strong evidence of confounding; factors that were statistically significantly associated with LPL/WM risk in basic adjusted models remained statistically significant in multivariate analysis and the point estimates were largely unattenuated after inclusion of the covariates (Table 6).

\section{Discussion}

In a large-scale, international pooled case-control analysis of predominantly nonfamilial LPL/WM, risk was increased in those with a history of Sjögren's syndrome, systemic lupus erythematosus, $\mathrm{HCV}$ infection, and a family history of hematologic malignancy. These findings support and extend prior studies suggesting a role for conditions characterized by chronic immune stimulation and genetic factors in LPL/WM pathogenesis. Novel findings were a decreased risk for history of hay fever and high usual adult weight, an increased risk for smoking cigarettes for 40 or more years, and occupation as a medical doctor, and no evidence of an association for other lifestyle factors and occupations.

We observed a very strong association between LPL/WM risk and Sjögren's syndrome, in agreement with previous large-scale medical record-based studies in the United States and Sweden $(11,13)$. A marked increased risk was also observed for systemic lupus erythematosus, consistent with a report from one study in our pooled analysis (15), and a medical record study (13). Unlike the medical record studies, we did not find an increased risk for 
Table 6. Factors associated with lymphoplasmacytic lymphoma/Waldenström's macroglobulinemia risk, basic adjusted, and final stepwise model risk estimates*

\begin{tabular}{|c|c|c|c|c|c|c|}
\hline \multirow[b]{2}{*}{ Factor } & \multirow[b]{2}{*}{ Cases, No.t } & \multirow[b]{2}{*}{ Controls, No.t } & \multicolumn{2}{|c|}{ Basic adjusted modelł } & \multicolumn{2}{|c|}{ Final model ${ }^{\S}$} \\
\hline & & & OR $(95 \% \mathrm{Cl})$ & $P$ & OR $(95 \% \mathrm{Cl})$ & $P$ \\
\hline \multicolumn{7}{|l|}{ Sjögren syndrome } \\
\hline No & 174 & 6079 & Referent & \multirow[t]{2}{*}{.003} & Referent§ & \multirow[t]{2}{*}{.002} \\
\hline Yes & 3 & 9 & $13.2(3.42$ to 50.9$)$ & & $14.0(3.60$ to 54.6$)$ & \\
\hline \multicolumn{7}{|l|}{ Systemic lupus erythematosus } \\
\hline No & 270 & 10470 & Referent & \multirow[t]{2}{*}{.002} & Referent & \multirow[t]{2}{*}{.003} \\
\hline Yes & 4 & 24 & 8.73 (2.91 to 26.2$)$ & & 8.23 (2.69 to 25.2$)$ & \\
\hline \multicolumn{7}{|c|}{ Serology hepatitis $C$ virus infection } \\
\hline Negative & 201 & 5259 & Referent & \multirow[t]{2}{*}{.050} & Referent & \multirow[t]{2}{*}{$.075 \|$} \\
\hline Positive & 6 & 95 & $2.70(1.11$ to 6.56$)$ & & 2.51 (1.03 to 6.17$)$ & \\
\hline \multicolumn{7}{|l|}{ Hay fever } \\
\hline No & 218 & 7235 & Referent & \multirow[t]{2}{*}{.022} & Referent & \multirow[t]{2}{*}{.017} \\
\hline Yes & 64 & 2511 & $0.70(0.51$ to 0.96$)$ & & 0.73 (0.54 to 0.99 ) & \\
\hline \multicolumn{7}{|l|}{ Usual adult weight" } \\
\hline Quartile 1 (low) & 88 & 2432 & Referent & \multirow[t]{4}{*}{.015} & Referent & \multirow[t]{4}{*}{.024} \\
\hline Quartile 2 & 66 & 2377 & $0.68(0.49$ to 0.95$)$ & & 0.71 (0.51 to 0.99$)$ & \\
\hline Quartile 3 & 91 & 3115 & $0.70(0.52$ to 0.95$)$ & & 0.72 (0.53 to 0.98$)$ & \\
\hline Quartile 4 (high) & 79 & 3299 & $0.60(0.44$ to 0.83$)$ & & $0.61(0.44$ to 0.85$)$ & \\
\hline \multicolumn{7}{|l|}{ Duration of cigarette smoking } \\
\hline Nonsmoker & 118 & 4935 & Referent & \multirow[t]{6}{*}{.145} & Referent & \multirow[t]{6}{*}{.148} \\
\hline $1-20$ years & 44 & 2007 & $1.01(0.71$ to 1.44$)$ & & $1.01(0.71$ to 1.45$)$ & \\
\hline $21-30$ years & 39 & 1258 & $1.23(0.84$ to 1.79$)$ & & 1.26 (0.86 to 1.84$)$ & \\
\hline 30-39 years & 46 & 1235 & $1.32(0.93$ to 1.89$)$ & & $1.35(0.95$ to 1.94$)$ & \\
\hline$\geq 40$ years & 57 & 1194 & 1.49 (1.06 to 2.09$)$ & & 1.46 (1.04 to 2.05$)$ & \\
\hline Smoker, duration unknown & 2 & 88 & $1.14(0.27$ to 4.75$)$ & & $1.10(0.26$ to 4.66$)$ & \\
\hline \multicolumn{7}{|c|}{ Family history hematological malignancy } \\
\hline No & 177 & 7303 & Referent & \multirow[t]{2}{*}{.050} & Referent & \multirow[t]{2}{*}{$.060^{\#}$} \\
\hline Yes & 21 & 452 & 1.65 (1.03 to 2.65$)$ & & 1.64 (1.02 to 2.64$)$ & \\
\hline \multicolumn{7}{|l|}{ Occupation: medical doctor** } \\
\hline No & 177 & 6970 & Referent & \multirow[t]{2}{*}{.003} & Referent & \multirow[t]{2}{*}{.002} \\
\hline Yes & 6 & 43 & 5.23 (2.11 to 12.9$)$ & & 5.54 (2.19 to 14.0$)$ & \\
\hline
\end{tabular}

${ }^{*} \mathrm{Cl}=$ confidence interval; $\mathrm{OR}=$ odds ratio.

† The counts do not add up to the total number of cases/controls due to data missing by design or report.

₹ Adjusted for age, sex, race/ethnicity, and study.

$\S$ Adjusted for age, sex, race/ethnicity, study, Sjögren syndrome, systemic lupus erythematosus, serology hepatitis C virus infection, hay fever, usual adult weight, smoking duration, family history of hematological malignancy, and medical occupation.

$\| P$ value using likelihood ratio test; $P$ value using Wald test .021.

If Quartile 1 (<72.6 kg males, <58.1 kg females), quartile 2 (72.6-79.9 kg males, 58.1-64.9 kg females), quartile 3 (80.0-88.9 kg males, 65.0-74.7 kg females), quartile 4 ( $\geq 89.0 \mathrm{~kg}$ males, $\geq 74.8 \mathrm{~kg}$ females).

\# Occupation at any time in life (eight studies) or the longest held occupation (two studies); occupations coded according to the International Standard Classification of Occupations (ISCO), Revised Edition 1968 (53); code 061 = medical doctor.

rheumatoid arthritis (11), Crohn's disease (11), or autoimmune hemolytic anemia (13). However, our composite autoimmune variable indicated an increased risk for autoimmune conditions with activated $\mathrm{B}$ cells, but not activated T cells. This association is consistent with the finding that familial LPL/WM patients are twice as likely as unaffected relatives to report a history of autoimmune disorders (14). The pathogenic mechanism is believed to involve chronic antigen-driven inflammation and activated proliferating lymphocytes $(36,37)$.

We confirmed an association between LPL/WM risk and family history of hematologic malignancy (5-7). Our data favored an association with leukemia but not NHL, Hodgkin lymphoma, or multiple myeloma, in partial agreement with a case-control study (7) that reported coaggregation with chronic lymphocytic leukemia and NHL, but not Hodgkin lymphoma or multiple myeloma. This association is thought to suggest a role for common susceptibility genes, as supported by an increased risk of LPL/WM among first-degree relatives of people with monoclonal gammopathy of undetermined significance $(9,38)$. Further, recent evidence of an association of both personal and family history of Sjögren's syndrome and autoimmune hemolytic anemia with LPL/WM risk (13) supports a role for shared susceptibility for LPL/WM and certain autoimmune conditions. At this time, information on specific genes or genomic regions in LPL/WM susceptibility is limited $(15,16,23)$.

The five studies in our analysis with HCV serology data formed the basis of an earlier InterLymph report showing a statistically significant association between HCV and LPL (12), consistent with US $(10,11)$, but not Swedish (13), medical record studies. The known association of HCV infection with type II mixed cryoglobulinemia and monoclonal gammopathy of undetermined significance (10), both of which increase LPL/WM risk $(39,40)$, supports a true association between HCV and LPL/WM. In addition, antiviral treatment can be an effective first-line therapy for 
HCV-positive LPL (40). HCV infection is believed to promote lymphomagenesis via chronic immune stimulation and elevated IgM levels (10,41-43).

Our finding of an inverse association between LPL/WM risk and personal history of hay fever is not consistent with prior studies that observed a positive $(13,14)$ or no association $(11,20)$ with individual allergic conditions or any allergy. Large-scale cohort study data are needed to clarify the relationship with this exposure (44).

Even though the relationship has not been previously examined, our observation that LPL/WM risk appears lower for individuals with higher adult weight is unexpected. Not only is there evidence of an increased risk of NHL and some other NHL subtypes for those of higher adiposity (45-47), but obesity is a chronic lowgrade inflammatory state characterized by lymphocyte proliferation (48). It is possible the association we observed is due to chance or selection bias. Uniquely to LPL/WM, however, IgM-producing $\mathrm{B} 1 \mathrm{~B}$ cells are found in milky spots on the omentum and fat-associated lymphoid clusters on the mesentery [reviewed in (49)]. It is possible their physical proximity to adipose tissue uniquely affects their physiology and progression to LPL/WM.

Although not entirely consistent across all of the smoking variables we examined, we found evidence of a weak positive association between LPL/WM risk and cigarette smoking. LPL/WM risk was increased 1.4-fold among those who had smoked for 40 or more years. Smoking history was not associated with LPL/WM risk in two previous studies, one based on 65 cases (20) and the other 103 cases (14). Although this finding requires confirmation in larger studies, a history of smoking has been weakly positively associated with other NHL subtypes (50), and an association is biologically plausible given the immunosuppressive effects of chronic cigarette smoke $(51,52)$.

We observed an elevated risk of LPL/WM for medical doctors but not health-care workers more generally. There is no prior evidence of such a relationship. We did not confirm the previously reported increased risk of familial LPL/WM and exposure to farming, pesticides, wood dust, and organic solvents (14); however, our analyses were limited to a small number of job titles rather than exposure to specific chemical compounds.

This is the first pooled analysis of medical history, lifestyle, family history, and occupational risk factors for LPL/WM using the 2001 and 2008 WHO classification for LPL/WM and pathology report review. It is the only observational study of LPL/WM to examine the role of potential effect modification and confounding and, thus, determine the independence of these putative risk factors. The exposure data are of high quality and the findings are generalizable to predominantly white populations because most studies were population based and were conducted in Europe, North America, and Australia.

Some limitations need to be considered. The study populations were predominantly Caucasian and the number of LPL/WM cases was relatively small, although this is one of the largest case-control interview-based studies of this rare lymphoma subtype to date. Given the rarity of LPL/WM, we undertook an exploratory analytical approach, without adjustment for multiple statistical tests. Lack of data on Ig levels, therapy for autoimmune diseases, duration and therapy for HCV, and history of infections other than $\mathrm{HCV}$ restricted our interpretation of some findings. We are also unable to exclude recall bias or reverse causality, with underlying LPL/WM misdiagnosed as Sjögren's syndrome or systemic lupus erythematosus. Further, misdiagnosis of MALT or splenic marginal zone lymphoma as LPL/WM is an alternative explanation for the associations we observed with autoimmune disease and HCV infection. Finally, our occupational analyses are based on job titles, not exposure to specific agents.

We have confirmed an association between LPL/WM risk and history of specific immune-stimulatory medical conditions and a family history of hematologic malignancy, and we have shown for the first time that these risk factors appear to be independent. These findings have future translational potential both biologically and clinically. Other novel findings, specifically the associations with hay fever, adult weight, smoking for 40 or more years, and occupation as a medical doctor, require confirmation in largescale case-control studies of LPL/WM and long-term cohort studies of monoclonal gammopathy of undetermined significance.

\section{References}

1. Swerdlow SH, Campo E, Harris NL et al., eds. World Health Organization Classification of Tumours of Haematopoietic and Lymphoid Tissues. 4th ed.Lyon, France: IARC Press; 2008.

2. Berger F, Isaacson PG, Piris MA, Vardiman JW. Lymphoplasmacytic lymphoma/Waldenstrom macroglobulinemia. In: Jaffe ES, Harris NL, Stein H, Vardiman JW, eds. Tumours of Haematopoietic and Lymphoid Tissues. Lyon, France: IARC Press; 2001:132-134.

3. Iwanaga $M$, Chiang CJ, Soda $M$, et al. Incidence of lymphoplasmacytic lymphoma/Waldenström's macroglobulinaemia in Japan and Taiwan population-based cancer registries, 1996-2003. Int 7 Cancer. 2014;134(1):174-180.

4. Morton LM, Wang SS, Devesa SS, et al. Lymphoma incidence patterns by WHO subtype in the United States, 1992-2001. Blood. 2006;107(1):265-276.

5. Altieri A, Bermejo JL, Hemminki K. Familial aggregation of lymphoplasmacytic lymphoma with non-Hodgkin lymphoma and other neoplasms. Leukemia. 2005;19(12):2342-2343.

6. Treon SP, Hunter ZR, Aggarwal A, et al. Characterization of familial Waldenstrom's macroglobulinemia. Ann Oncol. 2006;17(3):488-494.

7. Kristinsson SY, Bjorkholm M, Goldin LR, et al. Risk of lymphoproliferative disorders among first-degree relatives of lymphoplasmacytic lymphoma/Waldenstrom macroglobulinemia patients: a population-based study in Sweden. Blood. 2008;112(8):3052-3056.

8. Kyle RA, Therneau TM, Rajkumar SV, et al. Long-term follow-up of IgM monoclonal gammopathy of undetermined significance. Blood. 2003;102(10):3759-3764.

9. Landgren O, Kristinsson SY, Goldin LR, et al. Risk of plasma cell and lymphoproliferative disorders among 14621 first-degree relatives of 4458 patients with monoclonal gammopathy of undetermined significance in Sweden. Blood. 2009;114(4):791-795.

10. Giordano TP, Henderson L, Landgren O, et al. Risk of non-Hodgkin lymphoma and lymphoproliferative precursor diseases in US veterans with hepatitis C virus. FAMA. 2007;297(18):2010-2017.

11. Koshiol J, Gridley G, Engels EA, et al. Chronic immune stimulation and subsequent Waldenstrom macroglobulinemia. Arch Intern Med. 2008;168(17):1903-1909.

12. de Sanjose S, Benavente $Y$, Vajdic CM, et al. Hepatitis $C$ and non-Hodgkin lymphoma among 4784 cases and 6269 controls from the International Lymphoma Epidemiology Consortium. Clin Gastroenterol Hepatol. 2008;6(4):451-458.

13. Kristinsson SY, Koshiol J, Björkholm M, et al. Immune-related and inflammatory conditions and risk of lymphoplasmacytic lymphoma or Waldenstrom macroglobulinemia. 7 Natl Cancer Inst. 2010;102(8):557-567.

14. Royer RH, Koshiol J, Giambarresi TR, et al. Differential characteristics of Waldenstrom macroglobulinemia according to patterns of familial aggregation. Blood. 2010;115(22):4464-4471.

15. Smedby KE, Hjalgrim H, Askling J, et al. Autoimmune and chronic inflammatory disorders and risk of non-Hodgkin lymphoma by subtype. 7 Natl Cancer Inst. 2006;98(1):51-60. 
16. Wagner SD, Martinelli V, Luzzatto L. Similar patterns of V kappa gene usage but different degrees of somatic mutation in hairy cell leukemia, prolymphocytic leukemia, Waldenstrom's macroglobulinemia, and myeloma. Blood. 1994;83(12):3647-3653.

17. Aoki H, Takishita M, Kosaka M, Saito S. Frequent somatic mutations in D and/or JH segments of Ig gene in Waldenström's macroglobulinemia and chronic lymphocytic leukemia (CLL) with Richter's syndrome but not in common CLL. Blood. 1995;85(7):1913-1919.

18. Chng WJ, Schop RF, Price-Troska T, et al. Gene-expression profiling of Waldenstrom macroglobulinemia reveals a phenotype more similar to chronic lymphocytic leukemia than multiple myeloma. Blood.2006;108(8):2755-2763.

19. Liang XS, Caporaso N, McMaster ML, et al. Common genetic variants in candidate genes and risk of familial lymphoid malignancies. Br 7 Haematol. 2009;146(4):418-423.

20. Linet MS, Humphrey RL, Mehl ES, et al. A case-control and family study of Waldenstrom's macroglobulinemia. Leukemia. 1993;7(9):1363-1369.

21. Holly EA, Lele C, Bracci PM, et al. Case-control study of non-Hodgkin's lymphoma among women and heterosexual men in the San Francisco Bay Area, California. Am 7 Epidemiol. 1999;150(4):375-389.

22. Hughes AM, Armstrong BK, Vajdic CM, et al. Pigmentary characteristics, sun sensitivity and non-Hodgkin lymphoma. Int 7 Cancer. 2004;110(3):429-434.

23. Smedby KE, Hjalgrim $H$, Melbye $M$, et al. Ultraviolet radiation exposure and risk of malignant lymphomas. 7 Natl Cancer Inst. 2005;97(3):199-209.

24. Chatterjee N, Hartge P, Cerhan JR, et al. Risk of non-Hodgkin's lymphoma and family history of lymphatic, hematologic, and other cancers. Cancer Epidemiol Biomarkers Prev. 2004;13(9):1415-1421.

25. Spinelli JJ, Ng CH, Weber JP, et al. Organochlorines and risk of nonHodgkin lymphoma. Int 7 Cancer. 2007;121(12):2767-2775.

26. Chiu BC, Kolar C, Gapstur SM, et al. Association of NAT and GST polymorphisms with non-Hodgkin's lymphoma: a population-based case-control study. Br 7 Haematol. 2005;128(5):610-615.

27. Morton LM, Holford TR, Leaderer B, et al. Alcohol use and risk of nonHodgkin's lymphoma among Connecticut women (United States). Cancer Causes Control. 2003;14(7):687-694.

28. Besson H, Brennan P, Becker N, et al. Tobacco smoking, alcohol drinking and non-Hodgkin's lymphoma: a European multicenter case-control study (Epilymph). Int 7 Cancer. 2006;119(4):901-908.

29. Monnereau A, Orsi L, Troussard X, et al. History of infections and vaccinations and risk of lymphoid neoplasms: does influenza immunization reduce the risk? Leukemia. 2007;21(9):2075-2079.

30. Talamini R, Montella M, Crovatto M, et al. Non-Hodgkin's lymphoma and hepatitis $\mathrm{C}$ virus: a case-control study from northern and southern Italy. Int 7 Cancer. 2004;110(3):380-385.

31. Cerhan JR, Fredericksen ZS, Wang AH, et al. Design and validity of a clinic-based case-control study on the molecular epidemiology of lymphoma. Int 7 Mol Epidemiol Genet. 2011;2(2):95-113.

32. Jaffe ES, Harris NL, Stein H, Vardiman JW, eds. World Health Organization Classification of Tumours of Haematopoietic and Lymphoid Tissues. Lyon, France: IARC Press; 2001.

33. Morton LM, Turner JJ, Cerhan JR, et al. Proposed classification of lymphoid neoplasms for epidemiologic research from the Pathology Working Group of the International Lymphoma Epidemiology Consortium (InterLymph). Blood. 2007;110(2):695-708.

34. Turner JJ, Morton LM, Linet MS, et al. InterLymph hierarchical classification of lymphoid neoplasms for epidemiologic research based on the WHO classification (2008): update and future directions. Blood. 2010;116(20):e90-e98.

35. Higgins JP, Thompson SG. Quantifying heterogeneity in a meta-analysis. Stat Med. 2002;21(11):1539-1558.

36. Coussens LM, Werb Z. Inflammation and cancer. Nature. 2002;420(6917):860-867.

37. Fisher SG, Fisher RI. The emerging concept of antigen-driven lymphomas: epidemiology and treatment implications. Curr Opin Oncol. 2006;18(5):417-424.

38. McMaster ML. Familial Waldenstrom's macroglobulinemia. Semin Oncol. 2003;30(2):146-152.
39. Agnello V, Chung RT, Kaplan LM. A role for hepatitis C virus infection in type II cryoglobulinemia. N Engl 7 Med. 1992;327(21):1490-1495.

40. Mazzaro C, Franzin F, Tulissi P, et al. Regression of monoclonal B-cell expansion in patients affected by mixed cryoglobulinemia responsive to alpha-interferon therapy. Cancer. 1996;77(12):2604-2613.

41. Machida K, Cheng KT, Pavio N, et al. Hepatitis C virus E2-CD81 interaction induces hypermutation of the immunoglobulin gene in B cells. $\mathcal{F}$ Virol. 2005;79(13):8079-8089.

42. Fabris M, Quartuccio L, Sacco S, et al. B-lymphocyte stimulator (BLyS) up-regulation in mixed cryoglobulinaemia syndrome and hepatitis-C virus infection. Rheumatology (Oxford). 2007;46(1):37-43.

43. Lake-Bakaar G, Jacobson I, Talal A. B cell activating factor (BAFF) in the natural history of chronic hepatitis $\mathrm{C}$ virus liver disease and mixed cryoglobulinaemia. Clin Exp Immunol. 2012;170(2):231-237.

44. Vajdic CM, Falster MO, de Sanjose S, et al. Atopic disease and risk of non-Hodgkin lymphoma: an InterLymph pooled analysis. Cancer Res. 2009;69(16):6482-6489.

45. Willett EV, Morton LM, Hartge P, et al. Non-Hodgkin lymphoma and obesity: a pooled analysis from the InterLymph Consortium. Int 7 Cancer. 2008;122(9):2062-2070.

46. Murphy F, Kroll ME, Pirie K, et al. Body size in relation to incidence of subtypes of haematological malignancy in the prospective Million Women Study. Br 7 Cancer. 2013;108(11):2390-2398.

47. Bertrand KA, Giovannucci E, Zhang SM, et al. A prospective analysis of body size during childhood, adolescence, and adulthood and risk of nonHodgkin lymphoma. Cancer Prev Res. 2013;6(8):864-873.

48. Meijer K, de Vries M, Al-Lahham S, et al. Human primary adipocytes exhibit immune cell function: adipocytes prime inflammation independent of macrophages. PLoS One. 2011;6(3):e17154.

49. Kaminski DA, Randall TD. Adaptive immunity and adipose tissue biology. Trends Immunol. 2010;31(10):384-390.

50. Morton LM, Hartge P, Holford TR, et al. Cigarette smoking and risk of non-Hodgkin lymphoma: a pooled analysis from the International Lymphoma Epidemiology Consortium (InterLymph). Cancer Epidemiol Biomarkers Prev. 2005;14(4):925-933.

51. Sopori ML, Kozak W. Immunomodulatory effects of cigarette smoke. 7 Neuroimmunol. 1998;83(1-2):148-156.

52. Karavitis J, Kovacs EJ. Macrophage phagocytosis: effects of environmental pollutants, alcohol, cigarette smoke, and other external factors. 7 Leukoc Biol. 2011;90(6):1065-1078.

53. International Labour Office. International Standard Classification of Occupations, Revised Edition 1968. Geneva, Switzerland: International Labour Office; 1969.

\section{Funding}

This pooled analysis was supported by the Intramural Research Program of the National Cancer Institute/National Institutes of Health and National Cancer Institute/National Institutes of Health (R01 CA14690, U01 CA118444, and R01 CA92153-S1).

InterLymph annual meetings during 2010-2013 were supported by the Epidemiology and Genomics Research Program, Division of Cancer Control and Population Sciences, National Cancer Institute/National Institutes of Health (2010-2013); Lymphoma Coalition (2010-2013); National Institutes of Health Office of Rare Diseases Research (2010); National Cancer Institute/ National Institutes of Health (R13 CA159842 01) (2011); University of Cagliari, Provincial Administration of Cagliari, Banca di Credito Sardo, and Consorzio Industriale Sardo, Italy (2011); Intramural Research Program of the National Cancer Institute/National Institutes of Health (2012); and Faculté de Médecine de Dijon, Institut de Veille Sanitaire, Registre des hémopathies malignes de Côte d'Or, INSERM, Institut National du Cancer, Université de Bourgogne, Groupe Ouest Est d'Etude des Leucémies et Autres Maladies du Sang (GOELAMS), l'Institut Bergonié, The Lymphoma Study Association (LYSA), Registre Régional des Hémopathies de Basse Normandie, and the City of Dijon, France (2013). Meeting space at the 2013 Annual Meeting of the American Association for Cancer Research (AACR) was provided by the Molecular Epidemiology Group (MEG) of the AACR. Pooling of the occupation data was supported by the National Cancer Institute/National Institutes of Health (R03CA125831). 
Individual studies were supported by the Canadian Institutes for Health Research (CIHR), Canadian Cancer Society, and Michael Smith Foundation for Health Research (British Columbia); Intramural Research Program of the National Cancer Institute/National Institutes of Health (Iowa/Minnesota); National Cancer Institute/National Institutes of Health (N01-CP-ES-11027) (Kansas); National Cancer Institute/National Institutes of Health (R01 CA50850) (Los Angeles); National Cancer Institute/National Institutes of Health (R01 CA92153 and P50 CA97274), Lymphoma Research Foundation (164738), and the Henry J. Predolin Foundation (Mayo Clinic); Intramural Research Program of the National Cancer Institute/National Institutes of Health and Public Health Service (contracts N01-PC-65064, N01-PC-67008, N01-PC-67009, N01-PC-67010, and N02-PC-71105) (NCI-SEER); National Cancer Institute/National Institutes of Health (R01CA100555 and R03CA132153) and American Institute for Cancer Research (99B083) (Nebraska [newer]); National Cancer Institute/National Institutes of Health (N01-CP-95618) and State of Nebraska Department of Health (LB-506) (Nebraska [older]); National Cancer Institute/National Institutes of Health (R01CA45614, RO1CA154643-01A1, and R01CA104682)(UCSF1); National Cancer Institute/National Institutes of Health (CA143947, CA150037, R01CA087014, R01CA104682, RO1CA122663, and RO1CA154643-01A1) (UCSF2); National Heart Lung and Blood Institute/National Institutes of Health (hematology training grant award T32 HL007152), National Center for Research Resources/National Institutes of Health (UL 1 RR024160), and National Cancer Institute/National Institutes of Health (K23 CA102216 and P50 CA130805) (University of Rochester); National Cancer Institute/ National Institutes of Health (CA62006 and CA165923) (Yale); Association pour la Recherche contre le Cancer, Fondation de France, AFSSET, and a donation from Faberge employees (Engela); European Commission (QLK4-CT-2000-00422 and FOOD-CT-2006-023103), Spanish Ministry of Health (CIBERESP, PI11/01810, RCESP C03/09, RTICESP C03/10, and RTIC RD06/0020/0095), Rio Hortega (CM13/00232), Agència de Gestió d'Ajuts Universitaris i de Recerca-Generalitat de Catalunya (Catalonian Government, 2009SGR1465), National Institutes of Health (contract NO1-CO-12400), Italian Ministry of Education, University and Research (PRIN 2007 prot.2007WEJLZB, PRIN 2009 prot. 20092ZELR2), Italian Association for Cancer Research (IG grant 11855/2011), Federal Office for Radiation Protection (StSch4261 and StSch4420), José Carreras Leukemia Foundation (DJCLS-R04/08), German Federal Ministry for Education and Research (BMBF-01-EO-1303), Health Research Board, Ireland and Cancer
Research Ireland, and Czech Republic MH CZ - DRO (MMCI, 00209805) (EpiLymph); National Cancer Institute/National Institutes of Health (CA51086), European Community (Europe Against Cancer Programme), and Italian Alliance Against Cancer (Lega Italiana per la Lotta contro i Tumori) (Italy, multicenter); Italian Association for Cancer Research (IG 10068) (Italy, Aviano-Milan); Italian Association for Cancer Research (Italy, Aviano-Naples); Swedish Cancer Society (2009/659), Stockholm County Council (20110209), Strategic Research Program in Epidemiology at Karolinska Institute, Swedish Cancer Society (02 6661), Danish Cancer Research Foundation, Lundbeck Foundation (R19-A2364), Danish Cancer Society (DP 08-155), National Cancer Institute/National Institutes of Health (5R01 CA69669-02), and Plan Denmark (SCALE); Leukaemia \& Lymphoma Research, UK; and Australian National Health and Medical Research Council (ID990920), Cancer Council NSW, and University of Sydney Faculty of Medicine (New South Wales).

\section{Note}

We thank the following individuals for their substantial contributions to this project: Aaron D. Norman, Dennis P. Robinson, and Priya Ramar (Mayo Clinic College of Medicine) for their work at the InterLymph Data Coordinating Center in organizing, collating, harmonizing, and documenting of the data from the participating studies in the InterLymph Consortium; Michael Spriggs, Peter Hui, and Bill Wheeler (Information Management Services, Inc) for their programming support; and Noelle Richa Siegfried and Emily Smith (RTI International) for project coordination.

Affiliations of authors: Prince of Wales Clinical School, University of New South Wales, Sydney, Australia (CMV); Multiple Myeloma Section, Metabolism Branch (OL) and Division of Cancer Epidemiology and Genetics (MLM, JNS, LMM, MSL), National Cancer Institute, National Institutes of Health, Bethesda, MD; Department of Health Sciences Research, College of Medicine (SLS) and Division of Hematology (SMA), Mayo Clinic, Rochester, MN; Genome Sciences Centre, BC Cancer Agency, Vancouver, BC, Canada (AB-W); Department of Biomedical Physiology and Kinesiology, Simon Fraser University, Burnaby, BC, Canada (ABW); Epidemiology and Cancer Statistics Group, Department of Health Sciences, University of York, Heslington, York, UK (ASm); School of Nursing and Human Sciences, Dublin City University, Dublin, Leinster, Ireland (ASt); Department of Pathology, Memorial SloanKettering Cancer Center, New York, NY (AD). 